\title{
Bir Üniversite Modeli Önerisi: Yedinci Nesil Üniversite
}

\author{
Durmuş Günay \\ ${ }^{1}$ Maltepe Üniversitesi, Mühendislik Fakültesi, Marmara Eğitim Köyü, Maltepe, İstanbul. ORCID ID: 0000-0001-7461-2438
}

\begin{abstract}
Özet
Bu çalışmada, genel olarak üniversite için, ve özelde Türkiye üniversite sistemi için, bir model önerilmektedir. Modele "Yedinci Nesil Üniversite" adı verilmiştir. Söz konusu modelde üniversitede yapısal ve mahiyet düzenlemesi önerilmektedir. Yapısal olarak, üniversite sistemini destekleyen yeni fakülteler ve programlar öngörülmektedir. Mahiyet olarak; müfredat ve süre bakımından düzenlemeler önerilmekte, ve üniversitenin, değer dünyasına veya ruhuna dair gerekliliklere vurgu yapılmaktadır. Üniversite, zaman, mekan ve durum olarak kendisini merkez kabul eden bir tasavvur ile müfredatı yeniden düzenleyecektir.
\end{abstract}

Anahtar Kelimeler: bir üniversite modeli, yedinci nesil üniversite, üniversite sistemi

\section{A University Model Proposal: Seventh Generation University}

\begin{abstract}
In this study, a model is proposed for university in general, and especially for Turkish University System. The model is entitled as " 7 th Generation University". In the model proposed, the university will be as new essence and structure. Structurally, new faculties and programmes supporting to university system are suggested. As the essence of the university, arrangemets in curriculum and duration of education are proposed. The values and spirit of the university are also emphasized. The university will arrange the curriculum with a vision accepting itself as a center, time, place and situation.
\end{abstract}

Keywords: a university model; $7^{\text {th }}$ generation university; university system

\section{Giriș}

Bu yazıda, "Yedinci Nesil Üniversite" adını verdiğimiz yeni bir üniversite modeli önerilmektedir. "Yedinci Nesil Üniversite” kavramsallaştırması, Türkiye'nin üniversite tarihine ve mevcut sistemine dayalı olarak yapılmakla birlikte, tasarlanan model, çağımızda üniversite anlayışının geldiği nokta itibariyle, yalnız Türkiye için değil, genel olarak, yeni bir üniversite modeli olarak da düşünülebilir.

Türkiye'de, Cumhuriyet döneminde, 1933 Üniversite Reformu (33 Reformu) ile İstanbul Darülfünun'u kapatılıp İstanbul Üniversitesi kurulmuştur. İstanbul Üniversitesi ile üniversitenin yapısı ve akademik unvanlar olduğu gibi Batı'dan transfer edilmiştir. Böylece Darülfünun bütünüyle terkedilmiş, öğretim kadrosu da büyük ölçüde tasfiyeye uğramıştır (Günay\&Günay, 2017).

*Yazışma Adresi / Address for Correspondence:

Durmuş Günay, Email: dgunay@hotmail.com

Geliş Tarihi / Received Date: 17.11.2018

Kabul Tarihi / Accepted Date: 02.12.2018

Doi: 10.26701/uad.484582 1933'den günümüze kadar Üniversitede, Reform veya yeni düzenleme niteliğinde, altı önemli değişiklik yapılmıştır. Kendi tarihsel geçmişimize dayanarak her bir değişikliği bir nesil olarak kabul ederek, altı değișiklikten sonrası için önerilen bu yeni yapıya "Yedinci Nesil Üniversite" adı verilmiştir.

Başka toplumların kendi tarihsel geçmişleri, kültürel ve akademik yapıları sonucu ortaya çıkan üniversite için o ülkelerin düşünürleri veya kimi akademisyenleri tarafından, "Üçüncü Nesil Üniversite”, "Eğitim 4.0” veya benzeri kavramsallaştırmalar yapılmaktadır (Wissema, 2009; Öztemel, 2018). Farklı kültürel ve tarihsel süreçler yaşayan ülkelerin üniversiteleri için yapılan bu kavramsallaştırmaları, Türkiye için de geçerli saymak ontolojik bir illüzyon olsa gerektir.

Bir model önerisi yapmak için, önce üniversitenin özünün veya olagelen varoluşunun ne olduğuna bakmak gerekmektedir. Burada bir varolan olarak üniversitenin ne olduğuna değinildikten ve nesil nitelemesinin hangi dönemler göz önüne alınarak yapıldığı belirtildikten sonra, önerilen model dile getirilmiştir. 
1933'den sonra yapılan her bir reform veya düzenlemeyi bir nesil olarak kabul ettiğimiz altı değişikliği şöyle siralayabiliriz.

\section{CUMHURIYET DÖNEMINDE YAPILAN REFORM VEYA DÜZENLEMELER}

Birinci Nesil Üniversite (1933-1946 Dönemi): Bu dönem içinde; 1933'de, ilk Üniversite Reformu yapılmış ve 2252 Sayılı Yasa ile İstanbul Darülfünun'u kaldırılıp, yerine İstanbul Üniversitesi kurulmuştur. 33 reformu ile, özerklik kaldırılmış, ilk kez üniversite, rektör, fakülte, dekan gibi terimler ile akademik unvanlar benimsenmiştir. Darülfünun'un öğretim elemanları tasfiyeye tabi tutulmuş, Almanya>dan Nazi baskısından kaçan çok sayıda profesör üniversitede istihdam edilmiştir.

İkinci Nesil Üniversite (1946-1960 Dönemi): $13 \mathrm{Ha-}$ ziran 1946'da 4936 Sayılı Yasa çıkarılmış ve hem üniversiteye hem de fakültelere tüzel kişilik ile bilimsel ve idari özellik tanınmıștır. Bu Kanun ile Ankara Üniversitesi de kurulmuştur. İstanbul Üniversitesi, İstanbul Teknik Üniversitesi ve Ankara Üniversitesi aynı kanuna bağlanmıştır. Çok üniversiteli dönem başlamıştır.

Üçüncü Nesil Üniversite (1960-1971 Dönemi): 27 Mayıs 1960 askeri darbesinden sonra 115 Sayılı Kanunla 1946'da çıkarılan kanunda bazı değișiklikler yapılmıș ve Anayasaya ilk defa üniversite ile ilgili bir madde konulmuştur (Anayasa Madde 120).

Dördüncü Nesil Üniversite (1971-1981 Dönemi): 29 Eylül 1971 tarih ve 1488 Sayılı Kanunla, Anayasanın 120. Maddesinde değişiklik yapılmıştır. 7 Temmuz 1973'de 1750 Sayılı Üniversiteler Kanunu çıkarılmıştır. 1750 Sayılı Kanun ile Yükseköğretim Kurulu (YÖK) kuruldu. Ancak, Anayasa Mahkemesi tarafından, 1975 yılında Kanunun bazı maddeleri ile birlikte YÖK'ün kuruluşu ile ilgili madde iptal edildi.

Beşinci Nesil Üniversite (1981-2007 Dönemi): 6 Kasım 1981 tarih ve 2547 Sayılı Yükseköğretim Kanunu çıkarılmıştır. 1982 Anayasasına Yükseköğretim ile ilgili 130.131. ve 132. maddeler konulmuştur.

Altıncı Nesil Üniversite (2007-... Dönemi): Bu dönemde üniversite sisteminde önceki dönemlerden çok daha önemli düzenlemeler yapılmıș ve ayrıca yükseköğretimde çok büyük genişleme yaşanmıştır. Bir sistemin büyümesiyle sadece mevcut durum genişlemekle kalmıyor, aynı zamanda, kritik eşiği aşan büyüme, mahiyet değişikliğine de yol açmaktadır. Türk üniversitede sisteminde, 2007'den sonra yaşanan genişleme, üniversitenin mahiyetine dair değişikliklere de yol açmıştır.

Yedinci Nesil Üniversite: Burada önerilen yeni bir modeldir ve dolayısıyla aşağıda ortaya konulacaktır.

\section{YEDINCI NESIL ÜNIVERSITE}

Aşağıda, önce, mevcut üniversite kavramı ortaya konul- duktan sonra önerilen yeni modelin unsurları dile getirilecektir.

Felsefede bir varolanı meydana getiren dört neden belirtildikten sonra, bir varolan olarak, üniversite bağlamında bu nedenlerin her birini meydana getiren unsurlar dile getirilmiştir. Ardından, "Yedinci Nesil Üniversite"nin bünyesinde bulunması gereken birimler ile o birimlerin farklı özellikleri ortaya konulacaktır. Bu özellikler şekiller çizilerek açıklanmaya çalıșılmıștır (Şek. 1,2,3,...12).

Yedinci Nesil Üniversite: Üniversite, bir bilgi/bilim kurumu olduğuna göre, bilgi/bilim felsefesi zeminine (epistemolojik zemine) oturmalıdır. Bir makina, imal edilecek nesneye göre tasarlandığı gibi, bir kurum neyi amaçlıyorsa, o amacı gerçekleștirmeye uygun bir yapıda tasarlanmak zorundadır.

Yedinci Nesil Üniversite, örneğin Türk Üniversite Sistemi'nin mevcut yapısına ek olarak, yeni şu birimlere de sahip olacaktır: Araştırma Enstitüsü (AE), Felsefe Fakültesi, Dil Fakültesi, Bilişim ve İletişim Fakültesi (bu fakültenin tüm üniversiteler bünyesin de bulunması gerekmez) ve Uygulamalı Bilimler Fakültesi (Türk üniversite sisteminde bazı üniversitelerde bu adı taşıyan fakülte bulunmakla birlikte, burada önerilen fakülte yapısal olarak farklıdır).

Bütün bölümlerin hazırlık sınıflarında; o bölümün konusunun odağında olduğu Bilim Felsefesi ve Bilim Tarihi dersleri zorunlu ders olarak verilecektir. Ayrıca, hazırlık sınıfında, bir arkaik dil (örneğin, Yunanca, Latince, Arapça, Osmanlıca dillerinden biri) ile modern bir yabancı dil öğretilecektir. Arkaik dillerin ve modern yabancı dillerin öğretilmesi yabancı dil ile öğretim yapılması amacıyla değil, uluslararası bilime katkı ve bilimsel literatür ile iletişim amacına yöneliktir.

Müfredat; zaman itibariyle günümüzden geçmişe doğru, mekânda ise bulunulan yerden uzak yerlere ve üniversitenin bulunduğu noktadan evrensele doğru, Mevlana Pergeli tarzında genişleyen helezon vari şekilde, bir hiyerarşi ile düzenlenecektir. Örneğin tarihte, günümüzden eski çağlara; coğrafyada, yerelden dünya coğrafyasına doğru; edebiyatta mevcut çağdaş edebiyattan eski edebiyata, divan edebiyatına doğru; ve sorunlar yerelden evrensele doğru bir hiyerarşi gözetilerek ele alınacaktır. Bu durumda, Türkiye için, bütün müfredatın tersine çevrilmesi, kitapların buna göre yeniden yazılması, eğitim-öğretimin buna göre yapılması ve düzenlenmesi gerekecektir. Mevcut eğitim sisteminde öğrencinin bulunduğu mekandan uzaklardan başlayan ve zamanda geçmişten başlatılan müfredat tersine çevrilerek adeta öğrenciye dokunacak veya bitiştirilecektir.

Bütün bölümlerin lisans eğitimi süresi; ilk yıl hazırlık sınıfı ve 4 yıl eğitim-öğretim olmak üzere toplamda 5 yıl olacaktır.

\section{VAROLAN VE BIR VAROLAN OLARAK ÜNIVERSITE}

Felsefi açıdan üniversite de bir varolandır. Üniversiteye 
bir varolan olarak bakıldığında, Aristoteles'ten beri varolanı var eden dört neden vardır (Şek.1). Üniversitenin dört nedeninin her birini teşkil eden en temel unsurları belirledikten sonra, üzerine üniversiteyi inşa edeceğimiz bir zemin elde etmiş oluyoruz. Böylece, üniversitenin bütün nitelikleri bu zemin üzerinden konuşulabilir (Şek.2).

\subsection{Varolanın Dört Nedeni}

Aristoteles'ten (MÖ 384-322) beri varolanın varlığını borçlu olduğu dört neden şunlardır (Şek.1):

Maddi Neden (causa materialis); örneğin, varolan olarak bardağı göz önüne alırsak, bardağın yapıldığı cam.

Formal Neden (the causa formalis); bardağın formu, bardağın malzemesinin içine girdiği form (șekil).

Amaç/Erek Neden (causa finalis); bardağın imal edilme nedeni, örneğin çay içmek için.

Fail Neden (causa efficiens); bardağı yapan usta.

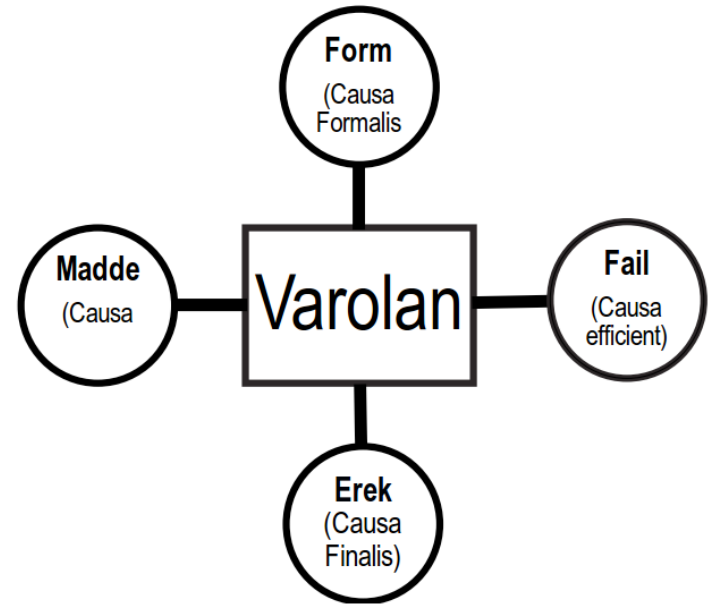

Şekil 1. Varolanın varlığını borçlu olduğu dört neden

\section{2 Üniversitenin Dört Nedeni ve Nedenleri Meydana Getiren Unsurlar}

Yukarıdaki şekilde gösterilen dört nedeni meydana getiren unsurlar üniversite için şöyle belirlenebilir (Şek.2):

- Fail Neden (causa efficiens); Akademik Kadro.

- Formal Neden (causa formalis); Müfredat (Araștır$m a+$ Eğitim + Kamu Hizmeti).

- Maddi Neden (causa materialis); Öğrenci + Fiziksel Alt Yap + Finansal Kaynak.

- Amaçsal/Ereksel Neden (causa finalis); İnsan gücü yetiștirilmesi + Bilim Üretimi + Teknoloji Üretimi + Danışmanlık.

\subsubsection{Fail Neden}

Üniversitenin formunu belirleyen ve idari kadronun da yardımı ile fonksiyonlarını yürüten, fail neden akademik kadrosudur. Akademik kadro üniversitenin formunu (özünü) belirler. Aristoteles'e göre form; o şeyi kendisi yapandır, yani özüdür. Fail neden; yükseköğretimin fonksiyonlarını (araştırma + eğitim-öğretim + kamu hizmeti) gerçekleștirir.

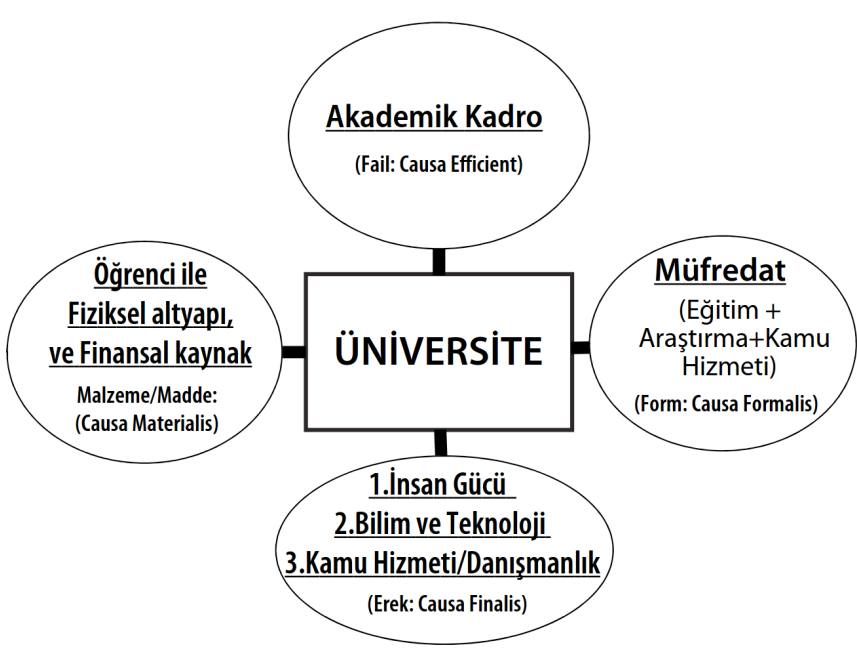

Şekil 2. Bir varolan olarak üniversitenin varlığını borçlu olduğu dört nedeni oluşturan unsurlar

\subsubsection{Formal Neden}

Üniversitenin formunu (özünü), müfredat (curriculum) oluşturur. Müfredat şunlardan meydana gelir: Eğitim-öğretim sistemi + içerik (dersler, deneyler, uygulamalar) + araştırma sistemi + kamu hizmeti sistemi.

\subsubsection{Maddi Neden}

Öğrenci + Fiziksel Alt Yapı + Finans Kaynağı'dan oluşur. Üniversitenin insan gücü yetiştirmesinin maddi unsuru öğrencilerdir. İnsan gücü yetiştirilmesi, Ar-Ge, ve inovasyon gibi çalışmalar; finansal kaynak, fiziksel altyap1, kütüphane, laboratuvar, ve bilgisayar donanımı gibi imkânlara muhtaçtır. Üniversitenin toplum nezdindeki saygınlığı; yetiștirdiği mezunlarla, bilimsel ve teknolojik ürünleriyle (makale ve benzeri yayınlar, patent, icat, inovasyon vb.) ve topluma verdiği hizmetlerle ortaya çıkar.

\subsubsection{Amaçsal/Ereksel Neden}

Üniversitenin üç nedenini şöyle sıralayabiliriz:

1. Toplumun ihtiyacı olan üst düzey insan gücü ihtiyacını ve kendi ihtiyacı olan akademisyenleri yetiştirmek.

2. Bilim ve teknoloji üretmek.

3. Topluma hizmet/danışmanlık hizmeti sunmak.

\section{5. ÜNIVERSITE SISTEMININ IŞLEYIŞi}

Bütün sistemlerde olduğu gibi üniversite sisteminin işleyişi; girdi, süreç ve çıtı ile gösterildikten (Şek.3) sonra, sistem bileșenleriyle birlikte bütün olarak Şek.4'de verilmiștir. Ayrıca, girdi, süreç ve çıktının alt bileşenleri șekillerle gösterilmiştir (Şek. 5, 6 ve 7):

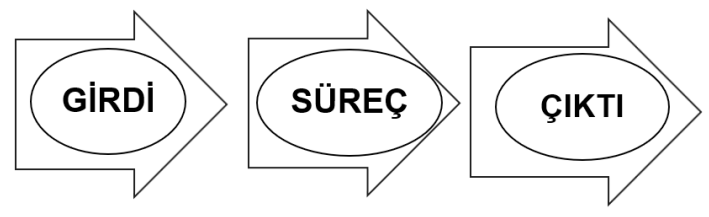

Şekil 3. Sistemin işleyişi 


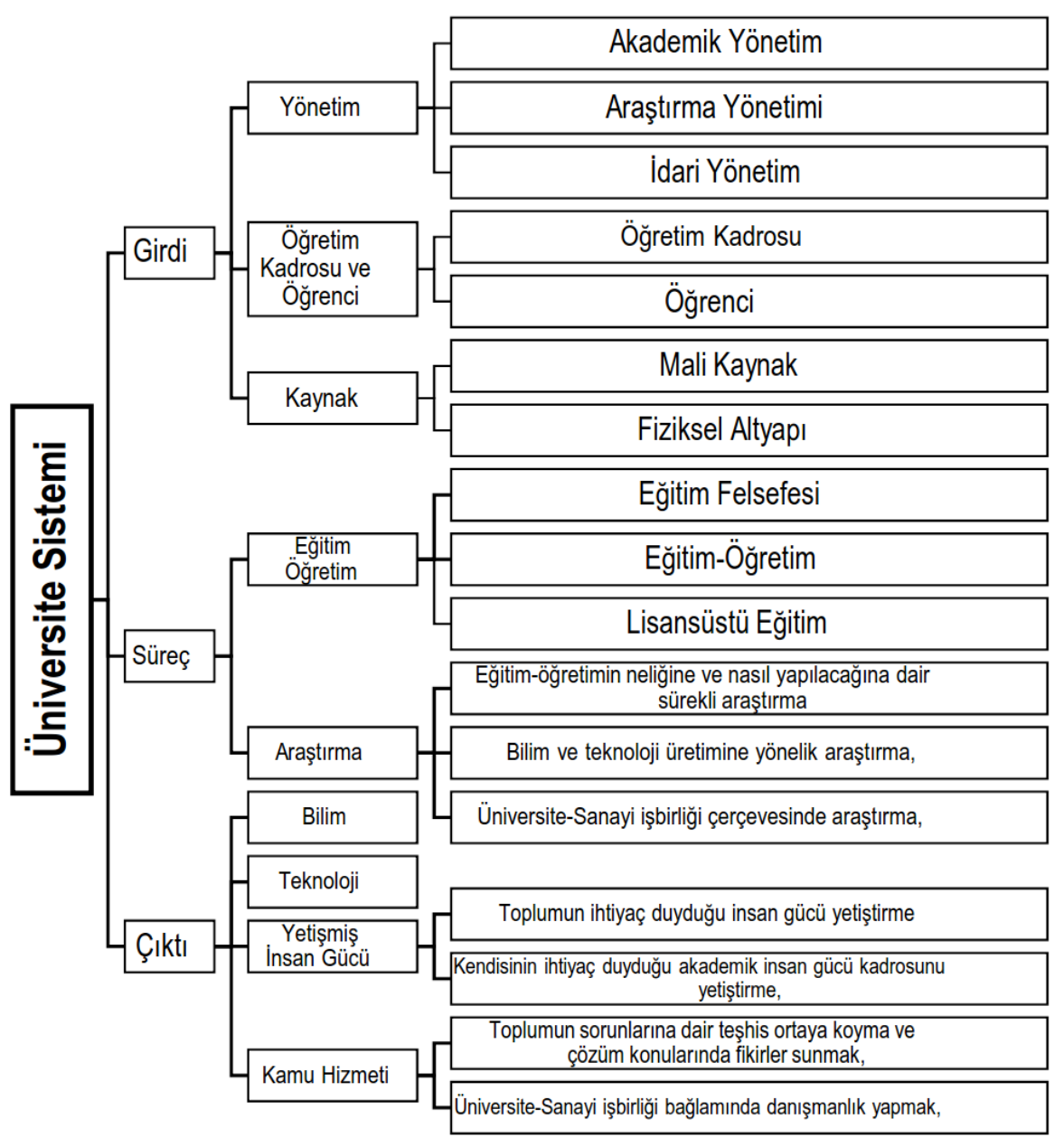

Şekil 4: Mevcut Üniversite Sistemi

\subsection{Girdi Bileșeni ve Alt Bileșenleri}

\subsubsection{Yönetim ve Alt Bileşenleri}

\section{Akademik Yönetim}

1. Eğitim-öğretim yönetimi

2. Araştırma yönetimi

3. İdari yönetim

Üniversite, akademik ve idari topluluk için coşku ile çalışabilecekleri bir ortam olmalıdır. Akademisyen üniversitede çalışmaktan derin bir haz duymalıdır.

\subsection{2 Öğretim Kadrosu ve Öğrenci}

Üniversitenin kalitesini büyük ölçüde öğretim kadrosu meydana getirir. Yüksek nitelikli öğretim kadrosu ile üniversite, adaylar için cazibe merkezi olmalıdır. Mensupları bünyesinde bulunmaktan kıvanç duymalıdır.

\subsubsection{Kaynak}

Üniversite, zengin mali kaynak, elverişli fiziksel altyapı (eğitim-öğretim mekanları, laboratuvar, kütüphane, kampüs vb.) imkanına sahip olmalıdır.

\subsection{Süreç Bileşeni ve Alt Bileşenleri}

\subsubsection{Eğitim-Öğretim}

Eğitim-Öğretim, felsefi bir zemin üzerine oturmalıdır. Eğer bilinçle yürütülen felsefi bir taban bulunmazsa, bü- tün yapıp etmeler bir sistem bütünlüğünden yoksun kalır. Lisansüstü eğitim akademik dünyanın kendini ürettiği alandır

\section{Eğitim felsefesi}

2. Eğitim-Öğretim

3. Lisansüstü eğitim

\subsubsection{Araştırma}

Başlıca araștırma alanlarını şöyle sıralayabiliriz:

Eğitim-öğretimin neliğine ve nasıl yapılacağına dair sürekli araştırma

Bilim ve teknoloji üretimine yönelik araştırma

Üniversite-Sanayi işbirliği çerçevesinde araştırma

\section{3. Çıktı Bileşeni ve Alt Bileşenleri}

Çıktı bileşenini meydana getiren alt bileşenler şekilde gösterilmiştir (Şek.7).

\subsubsection{Bilim Üretmek}

Bilim üretilmesi araştırmaya dayanır. Bilimsel ürün, bilimsel araştırma çalışmaların sonuçlarının yayımlandığı, akademik makale, diğer yayınlar, icat, patent, inovasyon vb. şeklinde ortaya çıkar. Bilimsel bir çalışma makale şeklinde ortaya konulmazsa o araştırma tamamlanmış olmaz. 


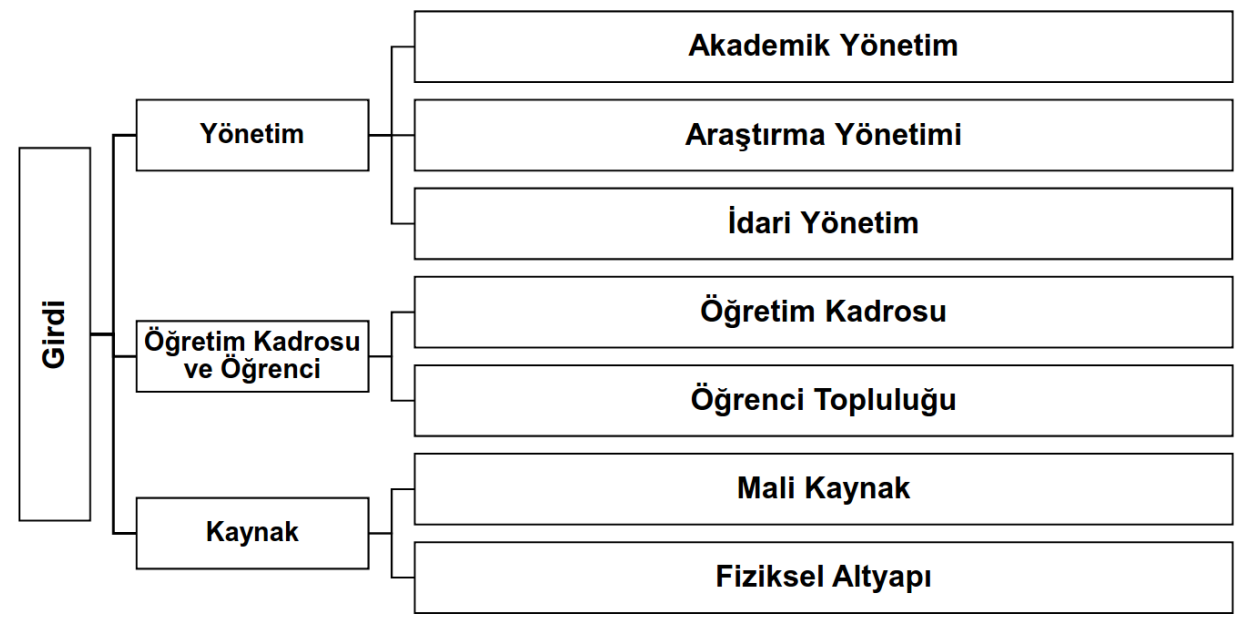

Şekil 5: Üniversite Sisteminin Girdi ve Alt Bileşenleri

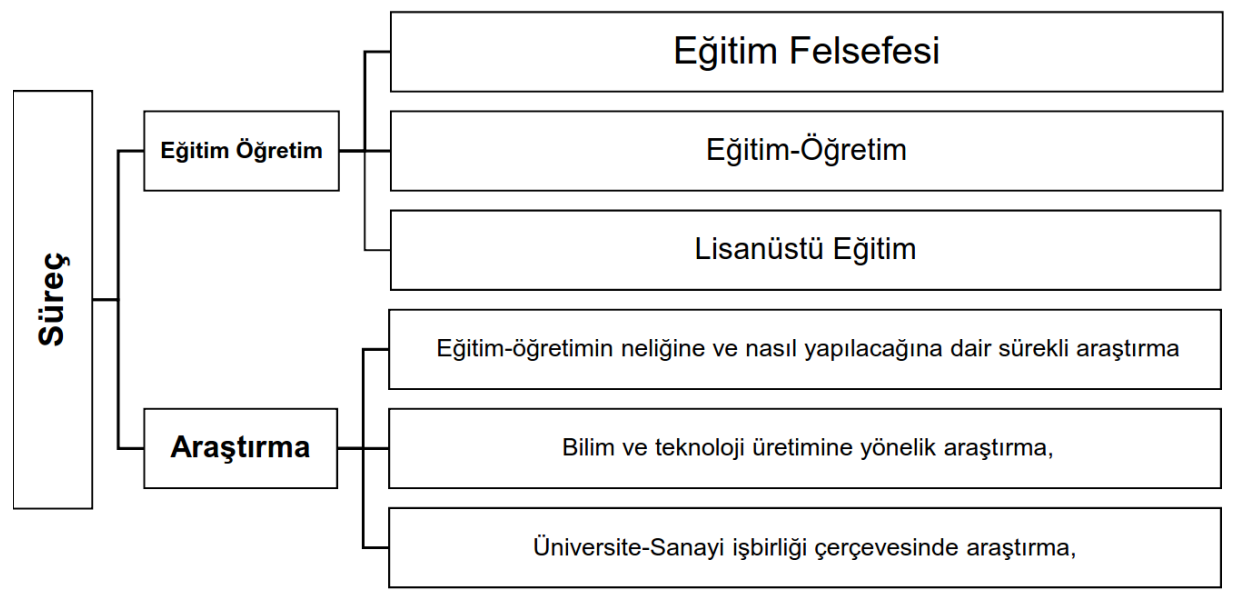

Şekil 6: Üniversite Sisteminin Süreç ve Alt Bileşenleri

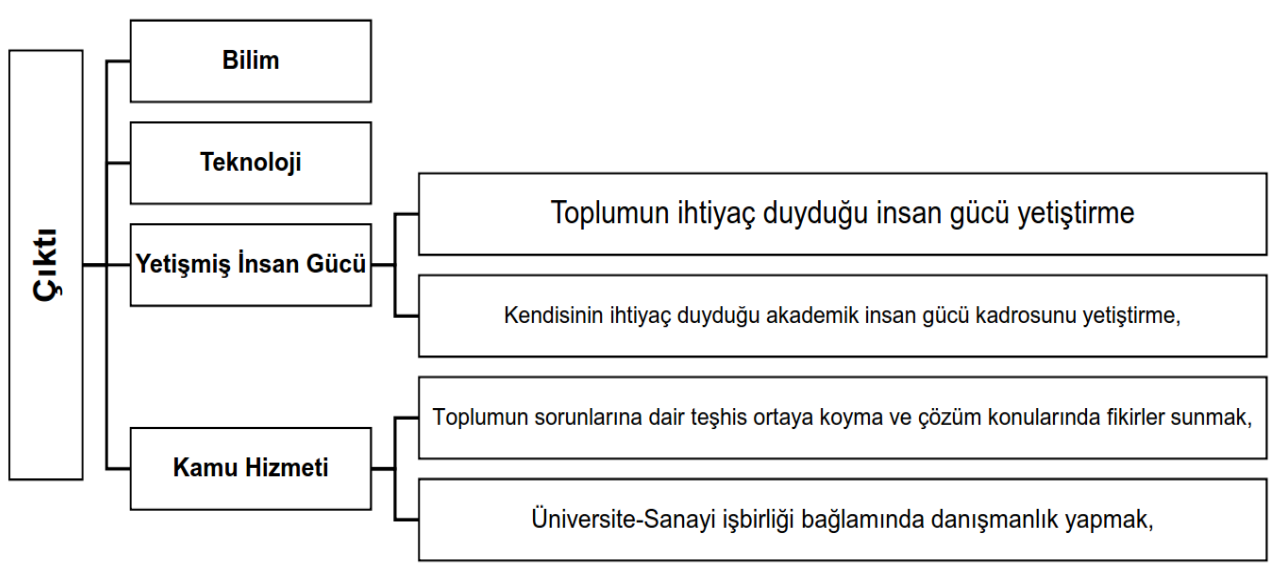

Şekil 7: Üniversite Sisteminin Çıktı Bileşeni ve Alt Bileşenleri

\subsubsection{Teknoloji Üretmek}

Teknolojinin özü, bilimde temellenir. Teknoloji, teknolojik ürünün imalatı sırasında bilim özününün malzeme ile birleştirilme bilgisidir diye tanımlanabilir. Böylece, dilde varolan bilimsel bilgi, madde/malzeme ile birleștirilerek teknolojik ürün olarak açığa çıkmaktadır. Bir makina projesi, projenin uygulanması ile fiziksel bir nesne olarak açığa çıkmaktadır. Makinanın kendisi teknolojik ürün olarak dış dünyada varolan, projesi ise dilde varolandır. Teknoloji, bir meydana getirmedir.

\subsubsection{Yetișmiș İnsan Gücü}

Üniversitenin misyonlarından veya çıktılarından biri de; toplumun ihtiyaç duyduğu üst düzey insan gücünü yetiştirme, diğeri ise kendisinin ihtiyaç duyduğu akademisyen kadrosunu yetiştirmektir.

\subsubsection{Kamu Hizmeti}

Üniversitenin kamu hizmeti, toplumun sorunlarına dair teşhis ortaya koyma ve çözüm konularında fikirler sunmak ve üniversite-sanayi işbirliği bağlamında danışmanlık yapmaktır. 


\section{FARKLI EĞiLIMLERE ODAKLANAN MEVCUT ÜNIVERSITELER}

Günümüzde farklı eğilimlere odaklanan üniversiteler, genel olarak, şöyle adlandırılabilir:

1. Geleneksel Üniversite (Do-lt-All University): Geleneksel üniversite modeli. Üniversitenin bütün fonksiyonlarına odaklanır.

2. Girişimci Üniversite (Do-lt-Different University): Girişimciliğe ve inovasyona odaklanır.

\section{Kalite Odaklı Üniversite (Do-It-Well University) :} Üniversite, kaliteye odaklanır.

Günümüzde; inovasyon ve girişimcilik ve kalite başat kavramlardır.

\section{7.ÜNIVERSITENIN MISYONU VE ZEMINI}

Bilgiye öznenin, üniversite bağlamında bilim adamının, varlık hakkında bir yargı ortaya koyması olarak bakıldığında, üniversitenin fonksiyonlarının üzerine oturtulacağı bir varlık zemini ve o zemine dayalı bir epistemolojisi (bilgi teorisi) bulunmak durumundadır (Şek.8).

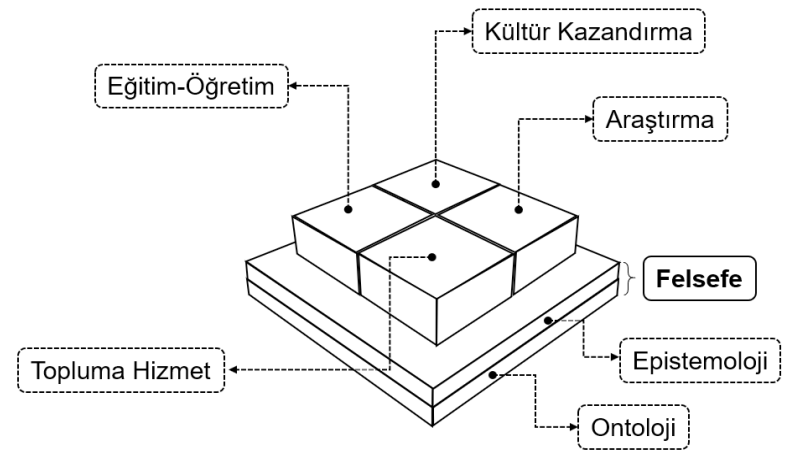

Şekil 8: Üniversitenin Felsefi Zemini ve Misyonu

\section{8. ÖNERILEN ÜNIVERSITE MODELİ: YEDINCI NESIL ÜNIVERSITENIN BIRIMLERI VE SISTEMI}

Önerilen üniversite modeli, aşağıda şekil halinde (Şek.9) gösterilmiştir. Bu modelde mevcut üniversite sistemindeki birimlere ek olarak bazı yeni birimler eklenmektedir. Eklenmesi önerilen birimler şekilde italik karakterde harfler ile yazılmıştır.

\section{9.ÜNIVERSITENIN KENDINI MERKEZE ALMASI}

Üniversitenin müfredatı zamanda, günümüzden geçmişe veya şimdiden tarihe doğru; mekânda, bulunduğu yerden uzak coğrafyalara doğru; konularda ise, şimdiden geçmişe doğru düzenlenmelidir (Şek.10).

Üniversitenin kendisini merkeze alması; Mevlâna pergeli gibi pergelin ayağı kendi bulunduğu yere batırılarak, diğer ucu giderek genişleyen bir helezon çizer gibi genişlemesi anlamındadır (Şek.11).

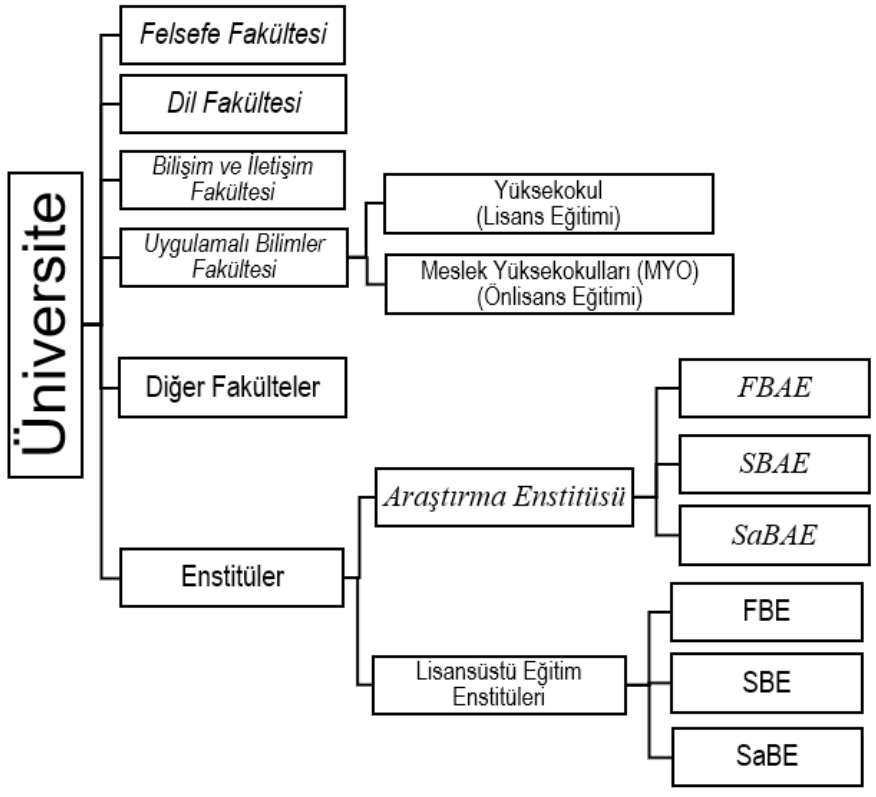

Şekil 9. Yedinci Nesil Üniversite Modeli. Şekilde, italik harf ile yazılmış olan birimler burada önerilen yeni birimlerdir. Diğer Fakülteler ibaresi ile kastedilen mevcut fakültelerdir.

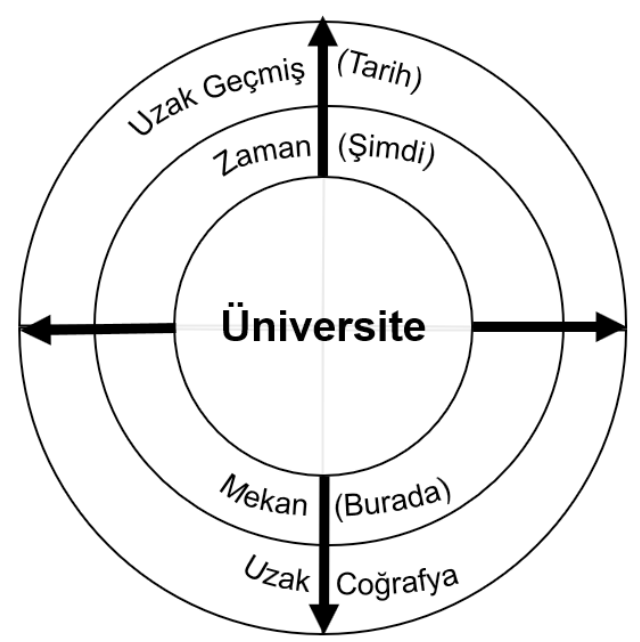

Şekil 10. Yedinci Nesil Üniversite Kendini Başlangıç Alır

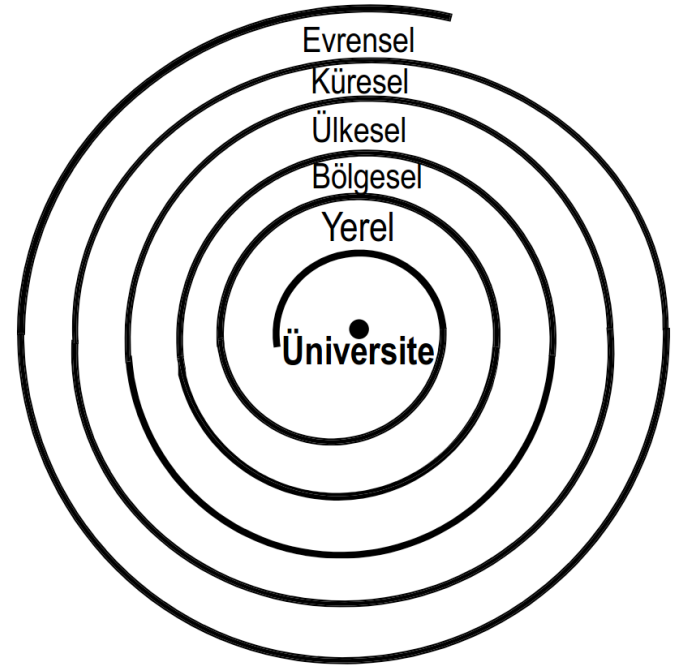

Şekil 11. Yedinci Nesil Üniversite Mevlâna Pergeli gibi Yerelden Evrensele Kadar Genişler 
10.YEDINCI NESIL ÜNIVERSITENIN FAKÜLTELERI VE ARAŞTIRMA ENSTITÜ(SÜ)/(LERI)

Yedinci Nesil Üniversite: Bu üniversitede, Türk üniversitelerinde (genelde bütün üniversitelerde) mevcut bulunan birimlere ek olarak aşağıdaki fakülteler ve araştırma entitüsü bulunması önerilmektedir (Şekil 9):

Felsefe Fakültesi

Dil Fakültesi

Uygulamalı Bilimler Fakültesi

Araştırma Enstitüsü

\section{YEDINCI NESIL ÜNIVERSITEDE EĞITIM VE EĞITIM SÜRELERI}

Üniversitede, mevcut fakültelerin ve önerilen fakültelerin bütün bölümlerinde eğitim süresi; 1 yıl hazırlık + 4 yıl eğitim-öğretim = 5 yıl olmalıdır. Uygulamalı Bilimler Fakültesinin kendi bölümlerinin de eğitim süresi 5 yıl olmalıdır. Ancak, Uygulamalı Bilimler Fakültesi bünyesindeki yüksekokulda lisans eğitimi 4 olabilir.

Bütün bölümlerde ilk yıl hazırlık sınıfı olacak ve her bölümün programında

\section{Bilim Felsefesi,}

\section{Bilim Tarihi ile,}

3. Dil Eğitimi (arkaik diller + modern diller) verilmelidir.

Felsefe Fakültesi: Felsefe Fakültesi servis dersleri veren bir fakülte olmakla birlikte, bünyesinde kendi eğitim bölümleri de bulunmalıdır/bulunabilir. Örneğin; bünyesinde Felsefe, Bilim Tarihi, Bilim Felsefesi vb. bölümler bulunabilir. Felsefe Fakültesinin servis misyonu, üniversitedeki bütün bölümlerin hazırlık sınıfında, bölümün alanının Bilim Tarihi ve Bilim Felsefesi derslerini vermektir.

Dil Fakültesi: Dil Fakültesi, sadece dil öğretimi fonksiyonu ile sınırlı olmayacak, dil üzerine araştırma da yapmalıdır.

1. Dilin kendisini araştıracak, ve bütün birimlerin dil eğitimini üstlenecektir.

2. Yunanca, Latince, Arapça ve Osmanlıca gibi arkaik dilleri de öğretecektir.

3. Fakülte bünyesinde, arkaik dillerin yanı sıra; modern yabancı dillerin eğitim-öğretimini de yapacaktır.

4. Örneğin, Felsefe bölümlerinde Yunanca, Tıp Fakültelerinde Latince, Tarih bölümlerinde Osmanlıca ve İlahiyat Fakültesinde Arapça vb. diller ile modern yabancı diller verilebilir.

Bilişim ve İletişim Fakültesi: Araştırmayı üniversitenin birincil fonksiyonu olarak kabul eden, 1810'da
Berlin'de Wilhelm Von Humboldt tarafindan kurulan üniversite tarzı Dünya çapında Humboldt Üniversitesi olarak yaygınlık kazanmıştı. Bu modelden sonra Alman üniversitelerindeki çok sayıda bilim adamı Nobel ödülü almıştır. Bu üniversite modelinde temel bilim araştırması üniversitenin en önemli fonksiyonu olarak kabul ediliyordu. Bu dönemde temel araştırmalara yönelik olarak Fen-Edebiyat alanı yaygınlık kazanmıștı. 33 Reformu ile Humboldt üniversitesi tarzında kurulmaya çalışılan Türkiye üniversitelerinin bünyesinde bu fakültenin bulunması zorunlu idi, fakat daha sonra bu zorunluluk kaldırıldı.

Benzer tarzda, bilişim ve iletişim çağı diyebileceğimiz 21. Yüzyılda, teknolojinin sadece kullanıcısı değil, aynı zamanda üretebilen bir ülke olmak için bilişim ve iletişim teknolojilerinin üniversite tarafından araştırılması zorunludur.

Uygulamalı Bilimler Fakültesi: Uygulamalı Bilimler Fakültesinin bölümlerinin eğitim süresi beş yıl; ancak bünyesinde kurulacak bir yüksekokulun eğitim süresi dört yıl olabilir. Türkiye bağlamında bakacak olursak, bütün Meslek Yüksekokulları (MYO), Uygulamalı Bilimler Fakültesine (UBF) bağlı olmalıdır. Böylece MYO’lar, UBF tarafından yönetilecektir. MYO yöneticileri Fakülte Yönetim Kurulu ve Fakülte Kurulunda yer alacaklar, ancak Üniversite Senatosunda ve Üniversite Yönetim Kurulunda Uygulamalı Bilimler Fakültesi tarafından temsil edileceklerdir.

Araştırma Enstitüsü (AE) salt araştırmaya yönelik olmalidir.

İş dünyasından alınan projeler üzerinde araştırma yapılacaktır.

Doktora sonrası (Post-Doc) araştırmalar yapılacaktır.

Araştırma Enstitüsü bünyesinde;

Fen Bilimleri Araştırma Enstitüsü (FBAE)

Sosyal Bilimler Araştırma Enstitüsü (SBAE)

Sağlık Bilimleri Araştırma Enstitüsü (SaBAE)

Araştırma Enstitüsü bünyesinde yukardaki üç araştırma enstitüsü yanısıra diğer araştırma ensitüleri de kurulabilir. Örneğin; Deprem Araştırma Enstitüsü, İnovasyon ve Girişimcilik (Ar-Ge, Teknoloji, Dijitalleşme) Araştırma Enstitüsü gibi.

Üniversitenin misyonu dile getirilirken ilk önce araştırma misyonu dile getirilir. Buna karşın, Türkiye'de üniversitenin bünyesinde araştırmaya hasredilmiş kurumsal bir birimin bulunmaması ilginçtir. Lisansüstü Eğitim Enstitüleri, yüksek lisans ve doktora eğitimine yöneliktir. Bu modelde kastedilen Araştırma Enstitüsü, tüm laboratuvarların bünyesinde yer aldığı ve tamamıyla araştırmayı hedefleyen bir enstitüdür. Lisansüstü eğitim enstitüsü öğrencileri de araştırma çalışmalarını AE bünyesinde yürütebilecektir. 


\section{Araştırma Enstitüsünün Yönetimi}

Araştırma Enstitüsüne (AE) ile bünyesinde alt birimleri Fen Bilimleri Araştırma Enstitüsüne (FBAE), Sosyal Bilimler Araştırma Enstitüsüne (SBAE) ve Sağlık Bilimleri Araştırma Enstitüsüne (SaBAE) Rektör tarafından birer müdür atanabilir. Araştırma Enstitüsü, Müdür ve Yürütme Kurulu tarafından yönetilir. Araştırma Enstitüsünde bir yürütme kurulu bulunur. Yürütme Kurulu, Araștırma Enstitüsü müdürü ve bünyesindeki araştırma enstitülerinin müdürleri ile her bir enstitüden birer öğretim üyesinden oluşur. Araştırma enstitüsünün altındaki enstitüler, müdür tarafından yönetilir, yönetim kurulu bulunmayabilir.

\section{Lisansüstü Eğitim Enstitülerinde Önerilen Termino- loji Değişikliği}

Burada Türkiye bağlamında bir benzerlikten doğan karmaşayı düzeltmek bakımından, ülkemizde lisansüstü programların adlarında kullanılmakta olan " Anabilim Dall" terimi "Alanı" terimi ile değiştirilmelidir. Türkiye'de, enstitüde "anabilim dalı" yerine "alanı" teriminin kullanılması hem bölümlerde ve hem enstitüde kullanılmakta olan "anabilim dalı" terimlerinin karıștırılmasını önleyecektir.

Lisansüstü program açıldığında, bölümün "Anabilim Dalı" adını alması mantıktaki özdeşlik ilkesine de aykırıdir.

\section{2.ÜNIVERSITE KÜLTÜRÜ: ÜNIVERSITENIN RUHU}

\section{1. Üniversitenin Ruhu, Tinsel (Manevi) Yanı}

Toplumsal varoluş kültür toprağında doğar ve yaşar. Kültürü oluşturan değerler, kemiyet (nicelik) değil, keyfiyettir (niteliktir). Sayı ile ifade edilemez. Bu nitelikler, örtük bilgi halinde, dile de getirilemez. Burada bir farkındalık ve bilinçlilik halinden bahsedilebilir. Üniversiteyi asıl var eden başka üniversitelere kolayca taşınamayan, onun manevi (tinsel) yanıdır. Üniversite, birimlerden oluşan mekanik bir yapı değil, ruhu olan canlı bir varlıktır. Üniversitenin ruhu dediğimiz şeyi oluşturan değerleri şöyle sıralayabiliriz: Aşk, Bilgelik, Fark, Yoğunlaşma, Derinlik, Adanmışlık, Mükemmellik, Genellik, Tümellik, Seçkinlik, Etik Illkler (Şek.12).

Ölçü ve Ölçütler

Aksiyom 1: Yükseköğretim alanında bütün ölçü ve ölçütler, uluslararası ölçü ve ölçütlerdir.

Aksiyom 2: Etik değerler en üst değerlerdir. Kalitenin ön koşuludur. Etik değerlerin çiğnendiği yerde varlığın anlamı boşalır. Sınırları aşan, sıfırlanır.

Aksiyom 3: Kalitenin de kalitesi olmalıdır. Kalitenin kalitesi; kalitenin, anlamı, ölçüsü, ölçütü, uygulaması ve bütün süreçlerinin yürütülmesinin kaliteli olmasına işaret eder.

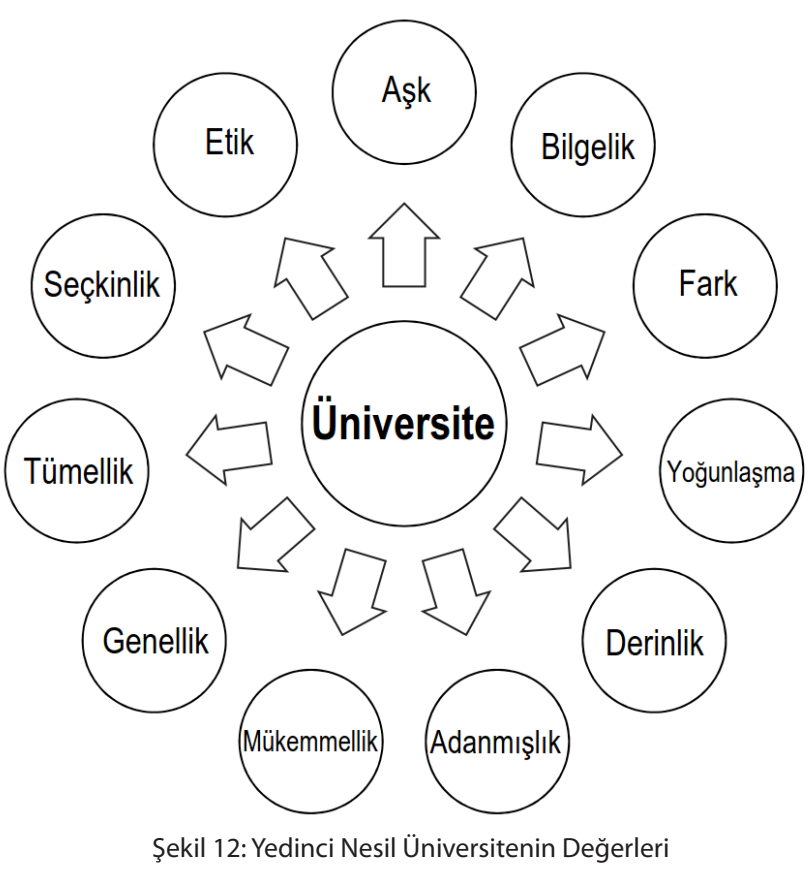

\section{3. ÜNIVERSITE NE OLMALIDIR?}

1. Bir şey hiç bir şey için olmadan önce kendisi ne ise o olmalıdır. Örneğin, üniversite bir endüstriyel kurum değildir. Sui generis nitelikleri vardır.

2. "Bilgi Kurumu" olarak daha üstü olmayan veya fikri derinlikte daha derini olmayan bir kurum olması gerekir.

3. Üniversitenin Felsefesi nedir? Üniversite, hakkında bilgi edindiği varlık zemini, yani ontolojisi ile epistemolojisi üzerine bilinçli bir şekilde kurgulanmalıdır.

4. Bir ülke, başka ülkenin kendisi için tasarladığı üniversite modelini olduğu gibi transfer edemez. Bir vücuda göre biçilmiş elbise, başka bir vücuda uymaz.

5. Üniversite, başkasına ayak uydurmak yerine, kendi zihniyle, kendisini kurmalıdır.

6. Üniversitenin tarih boyunca değişmeyen özü Hakikat arayıcılığıdır.

7. Üniversitenin üstlendiği fonksiyonlarının veya misyonunun temelinde hakikat vardır.

8. Hakikat genelde varlığın tümel bilgisidir.

9. Varlığın doğru bilgisine, bilimi de kapsayan tümel bilgi ile varilır.

10. Bilimsel bilgi araştırma ile ortaya konulur, eğitim-öğretim ile öğrenciye aktarılır, kamu hizmeti olarak topluma sunulur.

11. Ínsan bilgi ile eyler. Bütün yapıp etmelerimizin ve davranışımızın temelinde bilgi vardır. Davranış felsefesi etiğe, imal etmemizin bilgisi ise teknolojiye götürür.

12. Üniversite sıradanlaşmamalı, seçkin olmalıdır. Ancak, seçkincilik yapmamalıdır. Sıradanlık, duyarlılığı zayıflatır, aklı pörsütür, kişinin hassasiyetini, dikkatini, ve derinliğini zedeler. 
13. Üniversite tam bir etik ister, akademisyen doğru değil dosdoğru olmak durumundadır.

\section{SONUÇ}

Türkiye'nin belki de en kronik sorunu eğitim, özellikle yükseköğretimdir. Osmanlı modernleşmesinden beri, 1773'de Mühendishanenin kuruluşundan beri, Tanzimat öncesinde, çok sayıda yükseköğretim kurumu kuruldu. Tanzimat'tan Cumhuriyete kadar beş Darülfünun kuruldu ve kapandı. Cumhuriyetten sonra, üniversite sisteminde çok sayıda değişiklik yapıldı. Ama sorunlar orada hala durmaktadır. Bize göre bunun temel nedeni, çözümü doğru yerde aramamaktır. İkincisi kültürümüze araz olan derinlik zaafı veya yüzeyselliktir.

II. Meşrutiyet döneminde Maarif Bakanlığı yapan (19101912) Emrullah Efendinin “Tuba Ağacı Nazariyesi”ne göre, eğitim sistemini ıslah etmek için, yukardan başlamak, önceliği üniversiteye vermek gerekmektedir. Nazariyenin adını aldığı Cennette bulunan “Tuba Ağacı"nın kökleri yukarıda, dalları ve meyveleri aşağıdadır. Kökler, göklerdedir. Bilim de genelden özele doğrudur. Mantık dedüksiyona dayanır. İnsan düşünmesi, dedüktiftir, aksiyomatiktir. Euclides geometrisi başlıca beş aksiyoma dayanır. Felsefe; varlık vardır, bilgi mümkündür gibi aksiyomlara dayanır. Bilim, yasa taslağı olarak kabul edilen hipotez ile başlar. Tümevarım, Gazzali (1058-1111), D. Hume (1711-1776) ve K. Popper (1902-1994) tarafından çürütülmüştür. Tümevarımın geçerliliğini kanıtlamanın bir yolu yoktur, döngüseldir. Kanıtlama girişimi tümevarımın geçerliliğini baştan kabul etmeyi zorunlu kılmaktadır. Dolayısıyla, tekil olaylardan tümevarım yoluyla genellemeler yaparak yargilara/yasalara/teorilere varamayız. Ancak, verilmiş yargılardan hareketle tekil olayları açıklayabilir veya öndeyide bulunabiliriz.

Modern üniversite, modern bilim için örgütlenmiştir. İnsan, tanrı ve tabiat üçlüsünde, modern bilim Tanrı ile bağları koparmıştır. Dolayısıyla, modern bilimin epistemolojisi, insan ve tabiat ikilisinden oluşan bir ontolojiye dayanır.

Burada iki kavramsallaştırma yapmak isterim: Birincisi, üniversite modern bilimin ontolojisine ve epistemolojisine dayalı olarak bilinçli bir şekilde organize edilirse ve yürütülürse, buna üniversite için, Batı anlamında, yeniden doğuş diyebiliriz.

İkincisi, üniversitenin ontolojik ve epistemolojik zemininin içeriği yeniden belirlenebilir. Şöyle ki ontolojisi, medeniyetimizin tabanı olan insan, Tanrı ve tabiat üçlüsünün birlikteliği olursa ve epistemolojisi bu zemine dayandirllırsa, buna "üniversitenin diriliși" adını vereceğiz. Burada, bu kavramsallaştırmalar üzerinde bir izaha girmeyeceğiz. Basit fakat ontolojik tasavvuru dile getiren bir örnek ile yetineceğiz:

"Akyuvarlar, zararlı mikroplara karşı vücudu korumak için savaşırlar" ifadesi, Tanrının mevcudiyeti tasavvuru altında şöyle söylenebilir: "Akyuvarlar, vücudu korumak için mikroplarla savaşmak üzere görevlendirilmişlerdir". Böylece, insan, Tanrı ve tabiat üçlüsü bir ontolojiye ve bu ontolojiye bağlı bir epistemolojiye dayandırılırsa Yedinci Nesil Üniversite, Medeniyetimizin Üniversitesinin dirilişi: "Diriliş Üniversitesi” olacaktır.

Üniversite için; öncelikle üniversite kültürü, onun temeli olan örtük bilgi farkındalığı son derece önemlidir. Örtük bilgi, hakkında konuşulmayan ve aktarılamayan adeta üzeri örtülmüş bir konudur. Bu makalenin amacı dolayısıyla, burada son derece önemli olan örtük bilgi üzerinde durmayacağı. Üniversite esas itibariyle bilim kurumudur ve değişmeyen özü "hakikat arayıcılığıdır". Hakikat, için kurumsallaşmış bir yapıdır. Türkiye’nin kalbur üstü bir insan gücü kadrosuna; bilim, felsefe, ve sanat adamlartna, bilginlere, mucitlere, kaşiflere, inovatörlere ihtiyacı vardır. Bunun için köklü düzenlemeler yapılması ve zihniyet dönüşümü zorunludur.

Üniversite mekanik bir yapı, bir kurallar bütünü değil, öncelikle bir niteliktir, ruhtur. Sahici bilim merkezlerinde, tarihte de ve günümüzde bu böyledir. Çok sağlam bir lisans eğitiminin yanı sıra lisansüstü eğitimin özellikle doktora ve doktora sonrası araştırmanın çok önemsenmesi gerekmektedir. Bu yüzden lisans eğitimi döneminde, arkaik diller, yabancı modern diller, bilim felsefesi ve bilim tarihi ile, derin ve kapsamlı bir eğitimi başarmalıyız. Yukarda belirtildiği üzere, lisans eğitimi beş yıl olmalıdır. Ülkemizde en önemli sorun kendine değil daha çok Batıya bakan, bu yüzden özgüvenini yitiren bir zihinsel yapının oluşturduğu derinlik ve özgüven zafiyetidir. Kendi üzerine kıvrılıp kendi içine bakamayan zihinsel yapı, dışsallaşır ve derinlik yitimine uğrar. Üniversite öncelikle hakikati arayan kurumu ise, felsefi bir zemine oturması şarttır. Çünkü felsefe hakikat arayışıdır. Üniversite, aynı zamanda bilim kurumu olduğuna göre, bir bilim felsefesine dayanması, bu felsefenin epistemolojisine göre yapılandırılması gerekmektedir. Üniversite daha üstü olmayan en üst kurumdur. Üniversite kendinin bilincinde olarak alabildiğince derinleşmelidir.

\section{KAYNAKÇA}

Bok, D. (2007). Piyasa Ortamında Üniversiteler (B. Yıldırım, Çev.). İstanbul: İstanbul Bilgi Üniversitesi Yayınları.

Collins, H. M. (2001). Tacit Knowledge, Trust and Q of Sapphire. Social Studies of Science, 31(1), 71-85.

Çotuksöken, B. (2001). Felsefeyi Anlamak, Felsefe ile Anlamak. İstanbul: İnkilap Kitabevi.

Duralı, Ş. (2014).Felsefe- Bilim Nedir?. Istanbul: Dergâh Yayınevi.

Günay, D. (2011). Türk yükseköğretiminin yeniden yapılandırılması bağlamında sorunlar, eğilimler, ilkeler ve öneriler-I. Yükseköğretim ve Bilim Dergisi, 1(3), 113-121. doi:10.5961/ jhes.2011.017.

Günay, D. (2014). Türkiye'de yükseköğretimin mevcut durumu, sorunları, gelişmeler ve öneriler. Yeni Türkiye, 58, 678-945.

Günay, D. and Günay, A. (2017). Türkiye'de Yükseköğretimin 
Tarihsel Gelişimi ve Mevcut Durumu. Yükseköğretim Dergisi, 7(3), 156-178.

Heidegger, M. (1998). Bilim üzerine iki ders (H. Hünler, Çev.). İstanbul: Paradigma Yayınları.

Karakoç, S. (2012). Düşünceler I Kavramlar. 4. Baskı. Istanbul: Diriliş Yayınları

Karakoç, S. (2011). Düşünceler II Kurumlar. 3. Baskı. Istanbul: Diriliş Yayınları

Khun, T.S. (1962). The Structure of Scientific Revolutions. Chicago: London: University of Chicago Press.

Koyre, A. (2008). Bilim Tarihi Yazıları I (K. Dinçer, Çev.). Ankara: TÜBITAK Yayınları.

Tekeli, i. (2010). Cumhuriyet Öncesinde Üniversite Kavramının Ortaya Çıkışı ve Gerçekleştirilmesinde Alınan Yol, Türkiye'de Üniversite Anlayışının Gelişimi. N. K. Aras., E. Dölen, O. Bahadır (Eds.). Ankara: Türkiye Bilimler Akademisi Yayınları.

Özlem, D. (2013). Felsefe ve Doğa Bilimleri. İstanbul: Notos Yayınevi.

Özlem, D. (2012). Kültür Bilimleri ve Kültür Felsefesi. İstanbul: Notos Yayınevi.

Öztemel, E. (2018). Eğitimde yeni yönelimlerin değerlendirilmesi ve Eğitim 4.0. Üniversite Araştırmaları Dergisi, 1(1), 25-30.

Pinch, et. al. (1996). Inside Knowledge: Second Order Measures of Skill. Sociological Review, 44(2): 163-87.

Ural. Ş. (2017). Temel Mantık. 4. Baskı. İstanbul:Çantay Yayınları.

Wissema, J.G. (2009). Towards the third generation university: Managing the university in transition. Cheltenham. Edward Elgar Publishing.

Yıldırım, C. (2010). Bilim Felsefesi. İstanbul: Remzi Kitabevi.

Yıldırım, C. (2016). Bilim Tarihi. İstanbul: Remzi Kitabevi.

Şen, Z. (2017). Bilim ve Türkiye, Ankara: TÜBITAK Yayınları. 